Sección Básica / Basic

Artículo de investigación / Research paper

\title{
Land use and terrestrial arthropods at the Colombian Pacific coast
}

\author{
Uso de la tierra y artrópodos terrestres en la costa pacífica colombiana \\ BERNHARD LÖHR ${ }^{1}$; ALEXANDRA NARVÁEZ²
}

\begin{abstract}
${ }^{1} \mathrm{Ph}$. D. entomology, Colombian Corporation of Agricultural Research, Palmira Research Centre, Palmira, Valle del Cauca, Colombia, blohr55@gmail.com, https://orcid.org/0000-0003-4300-2551. ${ }^{2}$ M. Sc. Biology, Colombian Corporation of Agricultural Research, El Mira Research Centre, Tumaco, Nariño, Colombia,colexan@hotmail.com, https://orcid.org/0000-0002-7943-9491.
\end{abstract}

\section{Corresponding author}

Bernhard Löhr. Ph. D. entomology, Colombian Corporation of Agricultural Research, Palmira Research Centre, Palmira, Valle del Cauca, Colombia,blohr55@gmail.com, https://orcid. org/0000-0003-4300-2551.

\section{Suggested citation}

LÖHR, B.; NARVÁEZ, A. 2021. Land use and terrestrial arthropods at the Colombian Pacific coast. Revista Colombiana de Entomología 47 (1): e 7640. https://doi.org/10.25100/socolen. v47i1.7640

Received: 11-Mar-2019

Accepted: 14-Dec-2019

Published: 26-Feb-2021

Revista Colombiana de Entomología ISSN (Print): 0120-0488

ISSN (On Line): 2665-4385

https://revistacolombianaentomologia.univalle.edu.co

Open access

(c) (1) (2) (2) BY-NC-SA 4.0

Publishers: Sociedad Colombiana de Entomología SOCOLEN (Bogotá, D. C., Colombia) https://www.socolen.org.co

Universidad del Valle (Cali, Colombia)

https://www.univalle.edu.co

(C) 2021 Sociedad Colombiana de Entomología - SOCOLEN y Universidad del Valle - Univalle
Abstract: Diversity, permanence, and activity of terrestrial arthropods were investigated in four areas of different land use in the lowlands of the Pacific coast of Colombia with the aim to identify potential predator species for the palm root borer, Sagalassa valida. Ten pitfall traps were established along a $100 \mathrm{~m}$ transect in four areas: a secondary forest, a 20 year.-old peach palm plantation, and two hybrid oil palm plantations of three and seven years of age, respectively. Twenty-two collections were made covering a whole year. All ants were identified to species or morphospecies level, the other arthropods to order or where possible to family level. In total, 50,603 arthropods were captured, the most abundant were ants $(37.0 \%)$, followed by Collembola (35.4\%), Acari (10.6\%), Coleoptera (7.0 \%) and Diptera, Hemiptera and Araneae in almost equal numbers (around $2.5 \%$ ). Orthoptera (92\% Gryllidae) were present in all collections, always at low numbers. The highest number of ants were recorded in the oil palm transects; Diptera, Hemiptera and Orthoptera were more numerous in the secondary forest, Acari, Araneae and Collembola in the palm transects. Ectatomma ruidum was by far the dominant ant species ( $84.9 \%$ of all specimens) and absent from only 20 of the 880 captures. The second most frequent ant genus were army ants with two species, Labidus praedator and L. coecus. Rainfall, even area-wide flooding, and temperature did not explain variability in captures of any taxonomic group satisfactorily. We conclude that E. ruidum might be the predator to provide control of the root borer and recommend further studies on its efficiency.

Keywords: Pitfall trapping, hybrid oil palm, natural control, Sagalassa valida, Ectatomma ruidum.

Resumen: La diversidad, la permanencia y la actividad de los artrópodos terrestres se investigaron en las tierras bajas de la costa del Pacífico de Colombia con el objetivo de identificar posibles especies depredadoras para el barrenador de la raíz de la palma de aceite, Sagalassa valida. Se establecieron diez trampas de caída a lo largo de un transecto de $100 \mathrm{~m}$ en cuatro áreas: un bosque secundario, una plantación de palma de chontaduro de 20 años y dos plantaciones híbridas de palma aceitera de tres y siete años, respectivamente. Se realizaron 22 recolectas cubriendo un año entero. Todas las hormigas se identificaron a nivel de especie o morfoespecie, los otros artrópodos se identificaron hasta orden o, cuando fue posible, a nivel de familia. En total, se capturaron 50.603 artrópodos, los más abundantes fueron hormigas $(37,0 \%)$, seguidos de Collembola $(35,4 \%)$, Acari $(10,6 \%)$, Coleoptera $(7,0 \%)$ y Diptera; Hemiptera y Araneae en porcentajes casi iguales (2,5\%). Los ortópteros (92\% Gryllidae) estaban presentes en todas las recolectas, siempre en números bajos. El mayor número de hormigas se registró en los transectos de palma aceitera; Diptera, Hemiptera y Orthoptera fueron más numerosos en el bosque secundario; Acari, Araneae y Collembola en el transecto de palma aceitera. Ectatomma ruidum fue la especie de hormiga dominante $(84,9 \%$ de todos los especímenes) y estuvo ausente en solo 20 de las 880 capturas. El segundo género de hormigas más frecuente fue el de las legionarias con dos especies, Labidus praedator y L. coecus. Las precipitaciones, incluso las inundaciones de toda el área, y la temperatura no explicaron satisfactoriamente la variabilidad en las capturas de ningún grupo taxonómico. Se concluye que $E$. ruidum podría ser el depredador que proporcione control del barrenador de la raíz y se recomiendan estudios adicionales sobre su eficiencia.

Palabras clave: Trampas de caída, palma de aceite híbrida, control natural, Sagalassa valida, Ectatomma ruidum.

\section{Introduction}

The African oil palm, Elaeis guineensis Jacq., 1897 (Arecaceae) was the main commercial crop in the Pacific lowlands around Tumaco in Nariño, Department of Colombia, until the arrival of bud rot led to the eradication of about 35,000 hectares 
of the crop (Corredor Ríos et al. 2008; Preciado et al. 2011). As a solution to the disease problem, oil palm breeders produced a hybrid (OxG) between the native congeneric species, Elaeis oleifera (Kunth) Cortés, 1897 and E. guineensis, with the aim to transfer the disease tolerance of the native species to the hybrid and thus overcome the problem. Since 2010, more than 10,000 hectares in the Tumaco area were replanted with OxG hybrids (Fedepalma 2015) and until now, these seem to resist the disease. However, other problems have arisen, one of these is a lepidopteran root borer, Sagalassa valida Walker, 1856 (Lepidoptera: Brachodidae) that affects the palms mainly during the establishment phase. This insect is known in many countries producing oil palm in South and Central America (Genty 1977; Genty et al. 1978) and is present in all areas producing oil palm in Colombia (Sáenz and Olivares 2008). Particularly in the Pacific area, it is considered a pest of economic importance (Peña Rojas and Jiménez Ochoa 1994; Pinzón Andersson 1995; Aldana de la Torre et al. 2000).

Chemical control of the pest is possible but expensive (Bernal et al. 2015), so other ways of handling the problem were looked for. The role of ants in limiting the root borer was investigated by Coral et al. (2004) who associated two species of Ponerinae, Pachycondyla harpax F., 1804 and $P$. obscuricornis Emery, 1890 (Hymenoptera: Formicidae) with reduced borer damage. However, the importance of ants as pest control agents has been attributed to dominant or co-dominant ant species (Fernández 1991; Way and Khoo 1992; López and Potter 2000; Gallego Ropero and Armbrecht 2005), and Ponerinae generally have small colonies and an unequal distribution (Baena 1993). Therefore, we were interested in knowing a) whether there was any ground predator species that could play a role in controlling the oil palm root borer; b) the effect of land use on their distribution and population; and c) the effect of rainfall and temperature on their activity and permanence. In case a ground-active predator was identified, further studies would be required to estimate its effect on the root borer and how it could be enhanced.

\section{Materials and methods}

Study site. All collections were performed at the research

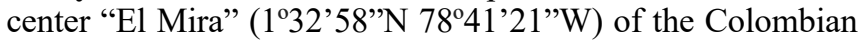
Corporation of Agricultural Research, located $38 \mathrm{~km}$ southeast of the municipality of Tumaco (Nariño, Colombia). The center is located at an altitude of 16 masl, with average temperature of $25.5^{\circ} \mathrm{C}$ and mean annual precipitation of $3,067 \mathrm{~mm}$ (Reyes 2012). It comprises of 564 ha of land dedicated to research in oil and peach palm (Bactris gasipaes Kunth), cacao Theobroma cacao L. and non-timber forestry products. The whole farm is in an area with high soil water table and prone to flooding after heavy rainfall. Rainfall data were obtained from the weather station at El Mira Research Center and temperature data from the weather station at Tumaco airport.

The collections were made in four areas, three contiguous and one at a distance of about $1 \mathrm{~km}$. Of the contiguous areas, one was a secondary forest regrowth, ten years of age and comprising of 14 ha, mainly populated by Cecropia $\mathrm{sp}$. The neighboring area was a juvenile ( 3 years at the onset of the collections) hybrid (OxG) oil palm plantation of 14 ha, next to the peach palm germplasm bank (9.9 ha, planted in 1997). The fourth area of $3 \mathrm{ha}$ at about $1 \mathrm{~km}$ distance was planted to OxG hybrids seven years of age when the experiment was set up. In the younger oil palm plantation, Engeo ${ }^{\mathrm{TM}} 247 \mathrm{SC}$ (thiametoxam and lambda-cyhalothrin) had been applied on February 16, 17/2016 (2.5 ml/1, soil application with knapsack sprayer) three months before the onset of our collections.

Layout of pitfall trapping. A transect of $100 \mathrm{~m}$ length was established with ten pitfall traps set at $10 \mathrm{~m}$ distance in each of the four described areas. The traps consisted of small $(150 \mathrm{ml})$ transparent plastic cups, two of which were stacked and buried to leave the upper rim of the top cup level with the soil surface. Both cups remained in place between the trapping events, the top cup covered with a lid. A roof made of three bamboo skewers (300 $\mathrm{mm}$ long) and a $250 \mathrm{~mm}$ diameter styrofoam plate was placed over the trap to avoid flooding during heavy rain. For the fortnightly trapping events, the top cup was replaced by a cup filled with $50 \mathrm{ml}$ water with a drop of dish-washing liquid to eliminate the surface tension. After 24 hours the collection cup was removed and replaced by the one with a cover. Collections started in May 2016 and in the course of one year, 22 collections were made with two collections per month except August 2016 and February 2017 with only one collection.

Processing of samples. The samples were taken to the lab and sorted under a stereomicroscope. The working team had a one-week hands-on training in ant taxonomy by a professional myrmecologist to whom also questionable specimens were sent for confirmation of the identification. Ants were separated into E. ruidum and others, and a sample of E. ruidum and all other ants were kept in $70 \%$ alcohol for later identification. All other arthropods were identified to order and family level wherever possible, recorded directly, and then discarded because of lack of space and containers. All ants except $E$. ruidum were conserved in numbered and labeled vials in $70 \%$ alcohol.

Data analysis. The data of the collections did not conform to a normal distribution and were therefore analyzed with the nonparametric Kruskall Wallis test. When significant differences in the dataset were detected, the means were separated following the method of Dunn (1961) with a $5 \%$ level of significance.

El Mira Research Center has a very high soil water table and in addition is occasionally affected by heavy floods. As this can be expected to affect the permanence and number of soil-nesting ants and other terrestrial arthropods, a linear correlation (Pearson 1895) was calculated between rainfall and the captures in all transects. The following scenarios were considered: the accumulated precipitation between subsequent collections, accumulated precipitation during the three days before the collections and rainfall of the day the samples were recovered from the field. In order to assess the impact of the floods, the numbers of all arthropods and ants in the collection before the flood events were compared with the collection immediately afterwards. Floods for this purpose were defined as $>100 \mathrm{~mm}$ of rain in a day. Similarly, a linear correlation was calculated between maximum and minimum temperatures the day of placement of the pitfall traps and the average temperature calculated the day of collection of the pitfall traps.

The independence of individual trap catches was analyzed by comparing the numbers of ants captured by all traps within a transect with the hypothesis that the outer traps capture more because of the lack of competing traps on one side. The 
ant numbers were verified for normal distribution and the differences analyzed with the Kruskall-Wallis test as described before.

\section{Results}

Taxa captured. In 22 pitfall trapping events covering a whole year, a total of 50,603 arthropods were captured (Table 1) of which 18,706 were ants $(37.0 \%)$ (Table 2$)$. In addition to the ants, a wide variety of arthropods were collected in the traps. These were grouped according to order (Diptera, Hemiptera, Coleoptera, Orthoptera, Araneae, Acari and Collembola), the remainder was lumped together under "other arthropods". Collembola were the most abundant $(17,929$ or $35.4 \%$ of the collected specimens), followed by Acari (5,349 or $10.6 \%$ ), Coleoptera $(3,538$ or $7.0 \%)$, Diptera $(1,366$ or $2.7 \%)$, Hemiptera (1,262 or $2.5 \%$ ) and Araneae (1,259 or $2.5 \%$ ) (Table $1)$. Orthoptera and the remaining arthropods accounted for only 1.1 and $1.2 \%$ of the collected specimens, respectively.

A breakdown of the main orders to family level gave the following results: in Diptera, $41.2 \%$ were Drosophilidae and $5.5 \%$ Tephritidae, in Hemiptera $20.6 \%$ were Cydnidae and in Coleoptera 78.2\% Bostrichidae, $8.5 \%$ Nitidulidae, and $8.1 \%$ Staphylinidae. Ectatomma ruidum (Roger, 1860) (Hymenoptera, Formicidae) was the most abundant and consistently present ant species throughout the whole collection period with 15,450 specimens, $84.0 \%$ of all ants and $30.4 \%$ of all specimens collected. It was absent in only four (of a total of 220) traps in the secondary forest, in 13 of the peach palm plantation, and three and none of the younger and older hybrid oil palm plantation, respectively. The second most frequent group were army ants of the genus Labidus with a total of $1,332(7.1 \%$ of ants and $2.6 \%$ of the whole collection) specimens (Table 2).

Effects of land use. The highest total number of specimens originated in the older hybrid oil palm plantation $\left(\chi^{2}=9.0111\right.$, $\mathrm{df}=3, \mathrm{P}=0.02914)$. Overall specimen numbers were higher in the palm plantations than in the secondary forest, but the differences were only significant for the older hybrid plantation (Table 1). Captures of Diptera and Hemiptera were significantly higher in the secondary forest and the peach palm plantation than in the oil palm transects $\left(\chi^{2}=17.646, \mathrm{df}=3, \mathrm{P}<0.0005\right.$ and $\chi^{2}=25.326, \mathrm{df}=3, \mathrm{P}=1.32^{\mathrm{e}-05}$, respectively) (Table 1$)$. Coleoptera and Orthoptera numbers were significantly more numerous in the secondary forest than in the other transects $\left(\chi^{2}=\right.$ $28.388, \mathrm{df}=3, \mathrm{P}<3.01^{\mathrm{e}-06}$ and $\chi^{2}=23.397, \mathrm{df}=3, \mathrm{P}<3.337^{\mathrm{e}-05}$, respectively). The highest captures of Acari were recorded from the three palm transects $\left(\chi^{2}=5.9925\right.$, $\mathrm{df}=3, \mathrm{P}=0.112$, not significant), the highest record of Araneae was registered in peach palm with the forest and oil palm transects significantly lower $\left(\chi^{2}=15.526, \mathrm{df}=3, \mathrm{P}<0.0014\right)$. Collembola were recorded in only 19 capture events because of lack of manpower for the counts of the last three collections. Nevertheless, they were the group with the second highest record and with large differences between older oil palm transects $\left(\chi^{2}=17.947, \mathrm{df}=\right.$ $3, \mathrm{P}=0.00045)$ followed by peach palm, younger oil palm and forest transects, all differences significant.

Diptera and Coleoptera were captured in all traps and collections, spiders and mites were also present in most collections. In contrast, Collembola numbers fluctuated widely (between zero and 1,327 in one single trap), and total capture was much higher in all palm plantations than in the secondary forest (Table 1).

The total number of arthropods captured showed several distinct peaks, particularly in September 2016 (all transects), November 2016 (peach palm) and December 2016 (older oil palm hybrid). The greatest source for this variability were Collembola: on September $6^{\text {th }}$ (767 in peach palm, 1,393 in the older oil palm and 1,542 in the younger oil palm transects); on November $11^{\text {th }}(1,208$ in peach palm) and December $14^{\text {th }}(1,434$ in the older oil palm). When these were removed from the records, the variability in the whole dataset was much reduced.

While E. ruidum was present in almost all traps and collection events, Labidus spp. were highly concentrated in nine raid episodes (Table 3 ). Army ant raids (defined as events with 50 or more Labidus sp. in any one pitfall trap) occurred on nine occasions, most frequently in the secondary forest transect (five occasions), twice in the peach palm plantation and once each in the hybrid oil palm plantations. The highest number of army ants caught in any single trap were $160 \mathrm{~L}$. praedator in the peach palm transect and 289 if the collection of three neighboring traps of the same date are pooled.

Table 1. Pitfall trap collections of terrestrial arthropods in areas under different land use; El Mira Research Centre, Tumaco, Nariño, Pacific coast of Colombia. From April 2016 to March 2017, 22 collections of ten pitfall traps were made in each area.

\begin{tabular}{|c|c|c|c|c|c|c|c|c|c|}
\hline & $\begin{array}{l}\text { Total number } \\
\text { of collected } \\
\text { specimens * }\end{array}$ & Diptera & Hemiptera & Coleoptera & Araneae & Acari & Collembola & Orthoptera & $\begin{array}{l}\text { All other } \\
\text { arthropods }\end{array}$ \\
\hline \multicolumn{10}{|c|}{ Secondary forest } \\
\hline Mean \pm SD & $\begin{array}{c}1073.7 \pm 265.1 \\
\mathrm{~B} \\
\end{array}$ & $\begin{array}{c}53.2 \pm 19.8 \\
\mathrm{~A} \\
\end{array}$ & $\begin{array}{c}46.6 \pm 13.2 \\
\mathrm{~A}\end{array}$ & $\begin{array}{c}139.8 \pm 30.6 \\
\mathrm{~A}\end{array}$ & $\begin{array}{c}19.0 \pm 11.5 \\
\mathrm{C}\end{array}$ & $\begin{array}{c}115.4 \pm 104.6 \\
\mathrm{~B} \\
\end{array}$ & $\begin{array}{c}250.8 \pm 98.6 \\
\mathrm{D} \\
\end{array}$ & $\begin{array}{c}24.6 \pm 9.0 \\
\mathrm{~A} \\
\end{array}$ & $20.7 \pm 9.9$ \\
\hline \multicolumn{10}{|c|}{ Peach palm } \\
\hline Mean \pm SD & $\begin{array}{c}1252.2 \pm 177.4 \\
\text { B }\end{array}$ & $\begin{array}{c}35.0 \pm 13.0 \\
\mathrm{~A}\end{array}$ & $\begin{array}{c}41.2 \pm 13.9 \\
\mathrm{~A}\end{array}$ & $\begin{array}{c}104.4 \pm 32.5 \\
\text { B }\end{array}$ & $\begin{array}{c}58.5 \pm 34.8 \\
\mathrm{~A}\end{array}$ & $\begin{array}{c}132.2 \pm 43.6 \\
\text { A }\end{array}$ & $\begin{array}{c}505.4 \pm 182.7 \\
B\end{array}$ & $\begin{array}{c}14.4 \pm 5.2 \\
\text { B }\end{array}$ & $16.4 \pm 3.7$ \\
\hline \multicolumn{10}{|c|}{ Hybrid oil palm, 7 years } \\
\hline Mean \pm SD & $\begin{array}{c}1616.4 \pm 625.5 \\
\mathrm{~A} \\
\end{array}$ & $\begin{array}{c}22.9 \pm 9.3 \\
\mathrm{~B} \\
\end{array}$ & $\begin{array}{c}27.4 \pm 11.1 \\
B\end{array}$ & $\begin{array}{c}75.5 \pm 23.8 \\
C \\
\end{array}$ & $\begin{array}{c}24.8 \pm 15.3 \\
B\end{array}$ & $\begin{array}{c}148.7 \pm 65.7 \\
\mathrm{~A} \\
\end{array}$ & $\begin{array}{c}614.0 \pm 281.3 \\
\mathrm{~A} \\
\end{array}$ & $\begin{array}{c}12.1 \pm 5.8 \\
\mathrm{~B} \\
\end{array}$ & $17.5 \pm 8.9$ \\
\hline \multicolumn{10}{|c|}{ Hybrid oil palm, 3 years } \\
\hline Mean \pm SD & $\begin{array}{c}1119.1 \pm 573.3 \\
B\end{array}$ & $\begin{array}{c}22.5 \pm 12.9 \\
B\end{array}$ & $\begin{array}{c}11.7 \pm 3.1 \\
C\end{array}$ & $\begin{array}{c}34.1 \pm 8.9 \\
\mathrm{D}\end{array}$ & $\begin{array}{c}23.6 \pm 12.7 \\
B\end{array}$ & $\begin{array}{c}138.6 \pm 48.0 \\
\mathrm{~A}\end{array}$ & $\begin{array}{c}422.7 \pm 466.5 \\
C\end{array}$ & $\begin{array}{c}6.0 \pm 6.0 \\
C\end{array}$ & $10.0 \pm 5.1$ \\
\hline Total & $50,613 *$ & 1,366 & 1,296 & 3,538 & 1,259 & 5,349 & 17,929 & 571 & 646 \\
\hline
\end{tabular}

*Includes 18,812 ant specimens; values in columns with different letters are significantly different at $\mathrm{P}=5 \%$ or below. 
Table 2. Ants collected in 22 pitfall trap collections in a $100 \mathrm{~m}$ transect in areas under different land use: El Mira Research Centre, Tumaco, Pacific coast of Colombia, April 2016 to May 2017. Data shown are averages of 10 pitfall traps per transect.

\begin{tabular}{|c|c|c|c|}
\hline & All ants & Ectatomma spp. * & Labidus spp. ** \\
\hline \multicolumn{4}{|c|}{ Secondary forest } \\
\hline Mean $\pm \mathrm{SD}$ & $403.6 \pm 200.4 \mathrm{~B}$ & $279.4 \pm 139.8 \mathrm{~B}$ & $62.5 \pm 70.4 \mathrm{~A}$ \\
\hline \multicolumn{4}{|c|}{ Peach palm } \\
\hline Mean \pm SD & $349.0 \pm 113.1 \mathrm{~B}$ & $256.7 \pm 108.1 \mathrm{~B}$ & $53.8 \pm 49.1 \mathrm{~A}$ \\
\hline \multicolumn{4}{|c|}{ Hybrid oil palm, 7 years } \\
\hline Mean \pm SD & $672.8 \pm 406.6 \mathrm{~A}$ & $638.5 \pm 410.2 \mathrm{~A}$ & $10.3 \pm 30.2 \mathrm{~B}$ \\
\hline \multicolumn{4}{|c|}{ Hybrid oil palm, 3 years } \\
\hline Mean \pm SD & $458.7 \pm 102.5 \mathrm{AB}$ & $424.7 \pm 106.0 \mathrm{~A}$ & $6.6 \pm 13.3 \mathrm{~B}$ \\
\hline Total & 18,841 & 15,993 & 1,332 \\
\hline
\end{tabular}

The composition of the ant fauna was also significantly different $\left(\chi^{2}=14.91\right.$, df $\left.3, \mathrm{P}<0.01\right)$ between the secondary forest $(69.2 \%$ E. ruidum $)$ and peach palm $(73.6 \%)$ and the two oil palm transects $(94.6 \%$ E. ruidum older and $92.6 \%$ younger plantation).

Of a total of 880 pitfall traps deployed, only six did not yield results; four were damaged in transport (14 July 2016, P20T1, T2, T4, T5) and two (27 July 2016, P18T9, P18T10) were destroyed by hoofprints of horses.

Within transect variation. A statistical analysis of the variation of ant captures within the transects (Fig. 1) revealed differences between individual traps in the secondary forest $\left(\chi^{2}=\right.$ $46.28, \mathrm{df}=9, \mathrm{P}<0.000006)$, peach palm $\left(\chi^{2}=19,859, \mathrm{df}=9, \mathrm{P}\right.$ $<0.019)$, oil palm of seven years $\left(\chi^{2}=93.578, \mathrm{df}=9, \mathrm{P}<3.109\right.$ $\left.{ }^{\mathrm{e}-16}\right)$, with the exception of the oil palm of three years $\left(\chi^{2}=\right.$ $12.406, \mathrm{df}=9, \mathrm{P}<0.1914)$. However, these differences were trap-specific and did not depend on trap position as the first and last trapping positions did not consistently capture higher numbers despite not having competing traps on one side.

Influence of weather conditions on captures. Total rainfall during the collection period was $3,491 \mathrm{~mm}$ and the average temperature was $26.3^{\circ} \mathrm{C}$ (Fig. 2). Exceptional rainfall, followed by flooding of all transects, was registered on three occasions: May $14^{\text {th }} 2016(118.6 \mathrm{~mm})$, July $21^{\text {st }} 2016(104 \mathrm{~mm})$
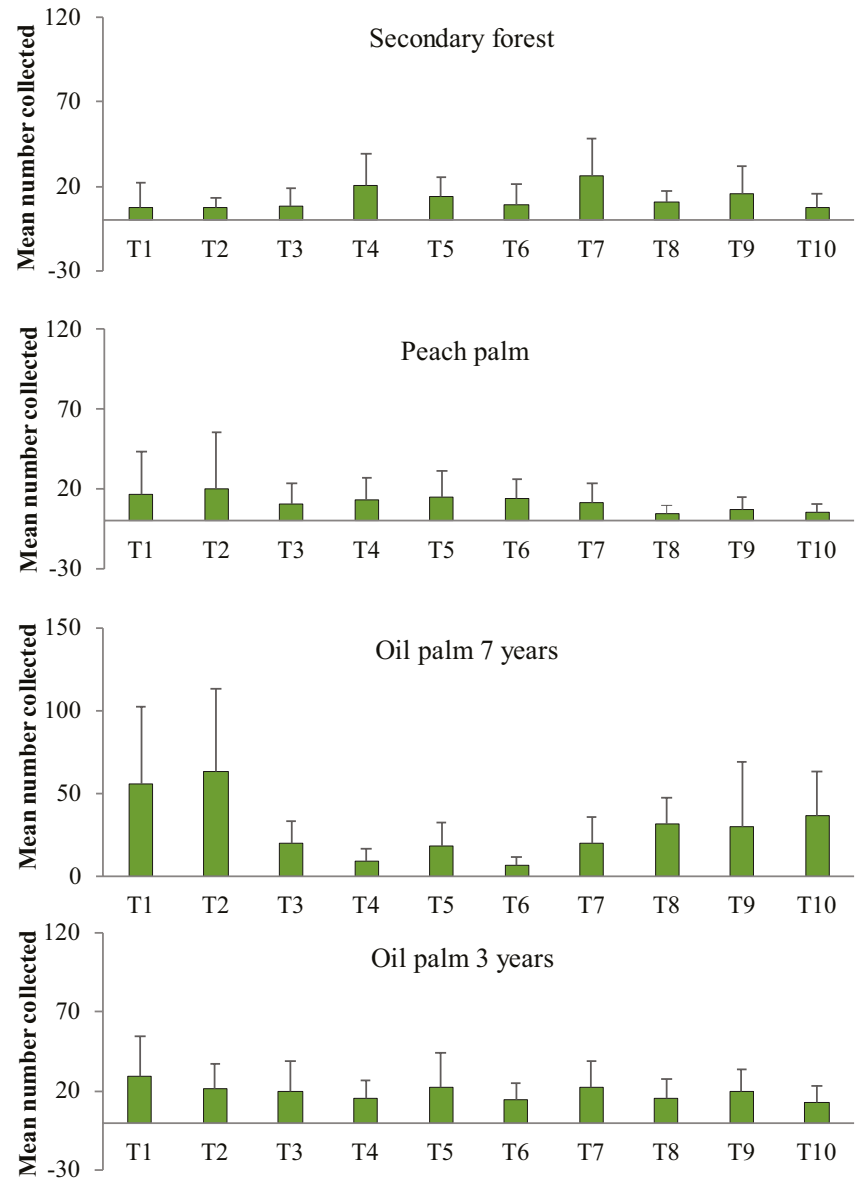

Trap number

Figure 1. Individual pitfall trap captures of Ectatomma ruidum in 100 $\mathrm{m}$ transects in four differently disturbed areas at El Mira Research Centre, Tumaco, Pacific coast of Colombia.

and January $20^{\text {th }} 2017(100.2 \mathrm{~mm})$. Correlation coefficients between rainfall and arthropod captures in all transects were low and did not surpass 0.53 , no matter which rainfall period before or on the day of collection was tested. Even though some of the correlation coefficients were significant, the variability in the whole dataset does not allow for a conclusive statement on the relation between accumulated rainfall and arthropod captures. Even three events of total flooding of the fields failed to conclusively impact arthropod captures. While arthropod captures in the secondary forest were significantly reduced after the flooding in two of three and the $E$.

Table 3. Army ant raids recorded during one year in pitfall traps in four transects in areas under different land use. El Mira Research Center, Tumaco, Nariño, Pacific coast of Colombia, May 2016 - April 2017.

\begin{tabular}{cclc}
\hline Date & Trap position & Army ant species & $\begin{array}{c}\text { Number of ants } \\
\text { caught }\end{array}$ \\
\hline 12-May-2016 & Secondary forest, traps 2,4,7,8 & Labidus coecus & 100 \\
26-May-2016 & Secondary forest, traps 7,8,9 & Labidus praedator & 111 \\
30-Jun-2016 & Hybrid oil palm plantation, traps 8,10 & Labidus praedator & 62 \\
30-Jun-2016 & Peach palm plantation, traps 5,6 & Labidus praedator & 50 \\
14-Jul-2016 & Secondary forest, trap 2 & Labidus praedator & 48 \\
06-Sep-2016 & Peach palm plantation, traps 4-9 & Labidus praedator & 401 \\
06-Sep-2016 & Secondary forest, traps 4, 5, 6 & Labidus praedator & 153 \\
25-Oct-2016 & Hybrid oil palm plantation, trap 9 & Labidus praedator & 51 \\
14-Mar-2017 & Secondary forest, traps 4,5 & Labidus praedator & 88 \\
\hline
\end{tabular}




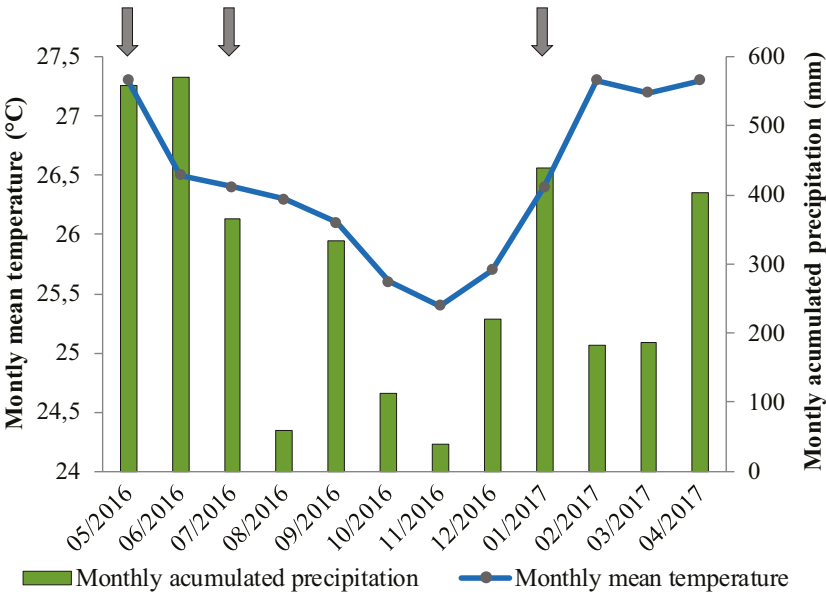

Figure 2. Monthly rainfall and mean temperatures at El Mira Research Center, Tumaco, Nariño, Pacific coast of Colombia (May 2016 - April 2017). Rainfall in excess of $100 \mathrm{~mm}$ per day marked with arrows.

ruidum captures in all three occasions, the effect in the palm plots was anything but uniform (Table 4). In addition, similar and even considerably higher variability between two subsequent collections occurred in all transects in absence of rainfall extremes. This was registered on eleven occasions, two of which in the secondary forest and with larger differences than those observed after flooding events.

Temperature throughout the whole year of collections fluctuated between $32.9{ }^{\circ} \mathrm{C}$ and $21.9{ }^{\circ} \mathrm{C}$, well within the optimal range for tropical insects, and thus had very little effect on the activity of all arthropods. This is reflected in the correlation coefficients between temperature and arthropod numbers captured in the pitfall traps. The highest value calculated was 0.29 (Collembola, minimum temperature, secondary forest) and almost all correlation coefficients were not significant.

\section{Discussion}

Arthropods are key to the maintenance of ecosystem functions (Weisser and Siemann 2004), such as pollination, leaf litter and dung decomposition or biological control of pests (Letourneau et al. 2009). Changes in terrestrial arthropod fauna following changes in land use showed that the reduction of plant diversity has serious consequences for arthropod diversity (Siemann et al. 1998; Goehring et al. 2002). More specifically, the conversion of primary forest to oil palm plantations generally has a negative impact on the richness and diversity of arthropod taxa including beetles (Chung et al. 2000; Davis and Philips 2005) and ants (Pfeiffer et al. 2008).

It is difficult to draw conclusions about species diversity from our collections because our records are of abundance of specimens not species. Nevertheless, some insight can be gained from our data. Even though the highest number of Coleoptera were captured in the secondary forest, the differences to the more disturbed areas were moderate. Differences were almost entirely due to a single family, Bostrychidae, borers and decomposers of woody material, which comprised between 84.9 and $66.3 \%$ of the Coleoptera collection in the four transects. The second most abundant family was Nitidulidae, decomposers of fallen fruits or in the case of young oil palms, of fruits not harvested; followed by Staphylinidae, a family of small predatory beetles. The almost total absence of Carabidae, a typical predatory species on the soil surface, is surprising with only 21 specimens in all collections combined.

Diptera, Hemiptera, and Orthoptera were more numerous in the secondary forest, whereas Acari, Araneae, and Collembola were more numerous in the palm transects. Particularly the latter were exceptionally abundant during several peaks, the cause of which is unclear. Another significant difference was the lower numbers of E. ruidum in the secondary forest, probably an effect of the higher canopy density and the resulting shade in the forest (McGlynn et al.

Table 4. Effect of flooding on arthropod captures in pitfall traps in four land-use systems at the Colombian Pacific coast.

\begin{tabular}{|c|c|c|c|c|}
\hline \multirow[b]{2}{*}{ Date of flooding } & \multicolumn{2}{|c|}{ All arthropods } & \multicolumn{2}{|c|}{ Ectatomma ruidum } \\
\hline & Before flooding & After flooding & Before flooding & After flooding \\
\hline \multicolumn{5}{|c|}{ Secondary forest } \\
\hline 14-Mar-2016 & 689 & 287 & 283 & 129 \\
\hline 21-Jun-2016 & 452 & 493 & 194 & 39 \\
\hline 20-Jan-2017 & 547 & 477 & 205 & 136 \\
\hline \multicolumn{5}{|c|}{ Peach palm plantation } \\
\hline 14-Mar-2016 & 348 & 256 & 237 & 54 \\
\hline 21-Mun-2016 & 890 & 550 & 465 & 40 \\
\hline 20-Jan-2017 & 345 & 583 & 67 & 210 \\
\hline \multicolumn{5}{|c|}{ Hybrid oil palm 3 years } \\
\hline 14-Mar-2016 & 475 & 521 & 396 & 421 \\
\hline 21-Jun-2016 & 360 & 543 & 204 & 277 \\
\hline 20-Jan-2017 & 408 & 386 & 77 & 205 \\
\hline \multicolumn{5}{|c|}{ Hybrid oil palm 7 years } \\
\hline 14-Mar2016 & 742 & 525 & 595 & 248 \\
\hline 21-Jun-2016 & 874 & 615 & 502 & 178 \\
\hline 20-Jan-2017 & 382 & 445 & 209 & 272 \\
\hline
\end{tabular}


2010). The reduced dominance of E. ruidum among the ants and the higher abundance of Coleoptera, Diptera, Hemiptera as well as Orthoptera in the forest transect might be interpreted as a partial return of the original diversity. Nevertheless, ten years of forest regrowth appears to be insufficient to reestablish a terrestrial arthropod community very distinct from the more disturbed areas.

The activity of the terrestrial arthropods as documented by the captures in the pitfall traps did not vary with the amount of rainfall. This is in stark contrast to observations of Nunes et al. (2011) and Delsinne et al. (2008), where ant numbers in semi-arid areas (Brazilian Caatinga and Paraguayan Chaco, respectively) were drastically reduced by rainfall. However, this could be expected, as our study area is part of the Chocó biogeographic region with rainfall records of up to $12,000 \mathrm{~mm}$. Furthermore, Lachaud (1990) stated that foraging activity of E. ruidum never completely stopped and resumed immediately after heavy rain. In our case, even complete flooding of the study area at three occasions did not produce higher levels of variation in the captures than those observed between captures without excessive rainfall. Temperature could also not be related to the variations in activity of any of the arthropods and the range was optimal for $E$. ruidum (Bestelmeyer 2008).

What stood out most in our collections, are the predatory ants. The absolute dominance of $E$. ruidum surprises, and the fact that this species was absent in only 20 out of 880 capture events confirms its ubiquity and the stability of its populations over time. The results of our study indicate that $E$. ruidum is a dominant species an important attribute of ants as agents for the natural control of insect pests (Majer 1972, 1976; Leston 1973, 1978; Way and Khoo 1992).

Ectatomma ruidum is mentioned as the most frequent and active predatory ant in oil palm cultivation (Zenner de Polania 1994). In the same study, Ectatomma quadridens (F. 1793 ) is mentioned as a predator of $S$. valida. In Colombia, $E$. ruidum has also been associated with predation of spittle bugs in pastures, insect pests of citrus (Abadia Lozano et al. 2013) and various pests of coffee (Mera Velasco et al. 2010). Velázquez et al. (2006) identified E. ruidum among the important predators of the agave weevil, Scyphophorus acupunctatus Gyllenhal, 1838 (Coleoptera: Curculionidae) in Venezuela with presence in almost all the sampled areas. The species has also been proposed as biological control agent of the banana weevil, Cosmopolites sordidus Germar, 1824 (Coleoptera: Curculionidae) in plantations of Musa spp. in Miranda State of Venezuela (Goitia and Cerdá 1998).

In previous studies in oil palm plantations of the Pacific region, Coral et al. (2004) associated two species of hunting ants, P. harpax and P. obscuricornis, to a low level of damage by $S$. valida. However, in our collections that covered four differentenvironments and aconsiderably longersamplingtime, only 25 specimens of this genus were collected. Apparently, Pachycondyla spp. depend on the microhabitat of large amounts of organic matter to nest, which was not available in our plots and in its absence, the species did not establish in high numbers. In addition, there are doubts about the preference of this genus for $S$. valida larvae (Sarmiento et al. 2005).

Ectatomma ruidum is a species with a wide geographical distribution, preferentially inhabiting the moist neotropical forests. This ant has a high trophic versatility that might be the reason for its wide distribution (Riera-Valera and Pérez-Sanchez 2009). Ectatomma ruidum workers have foraging habits for live prey, where they sting and carry their prey to the nest (Schatz et al. 1996).

Ectatomma ruidum has been categorized as a forest species by some authors, while others claim that it is a species adapted to disturbed areas (Fernández 1991; Zenner de Polania 1994). Our data indicate that the numbers are consistently higher in the most disturbed areas, which would support the second claim. The species is also known as a thermophile, since light-exposed areas generally have higher colony densities than adjacent shaded areas or forests with closed canopies (Lachaud 1990; Schatz and Lachaud 2008; Santamaría et al. 2009; McGlynn et al. 2010). This would explain its high abundance in the oil palm plantations and the relative scarcity in the secondary forest.

Wang and Foster (2015) have indicated that species composition of ground-foraging ant communities varies with different ages of oil palm, where older plantations show greater species homogeneity, with specialist predatory ants more abundant, as observed with E. ruidum in our study.

The comparison of individual ant catches within each transect was made to demonstrate the independence of trap catches. Only two outer traps of eight (at the end of the older oil palm transect) but also four interior traps had higher captures, which appears to confirm the independence of each trap.

\section{Conclusions}

In the present study, we show that the ants are the prevalent and most stable of the terrestrial arthropod communities and that Ectatomma ruidum is the dominant species in the four areas studied. Therefore, we can follow Lachaud who stated " $E$. ruidum is mainly carnivorous and considering the high density of nests of this species, its role as an element of biological control seems to be undeniable". We are convinced we have identified a terrestrial predator with the potential to provide the required pest control services in oil palm plantations at the Pacific coast. Further studies are necessary to elucidate the effectiveness of E. ruidum in removing root borer larvae and ways and means of its conservation and stimulation. We can also conclude that ten years of secondary forest recovery lead to measurable differences in arthropod diversity as compared to managed areas.

\section{Acknowledgements}

The studies reported here were conducted as part of the routine research activities of the Colombian Corporation of Agricultural Research, with funding from the Ministry of Agriculture (Ministerio de Agricultura, Pecuaria y Abastecimiento de Colombia). Carolina Ortiz and Manuel Sanchez are gratefully acknowledged for their support in field and laboratory activities. Manfred Palacio, Jackeline Gaviria, and Rubilma Tarazona assisted in the statistical analysis.

\section{Literature cited}

ABADIA LOZANO, J. C.; ARCILA CARDONA, A. M.; CHACÓN DE ULLOA, P. 2013. Hormigas en cultivos de naranja (Citrus sinensis L. Osbeck) de la costa Caribe de Colombia. Biota Colombiana 14 (3): 13-19. http://revistas.humboldt.org.co/index. $\mathrm{php} /$ biota/article/view/299

ALDANA DE LA TORRE, R. C.; CALVACHE G., H.; ZAMBRANO, J. 2000. Determinación del daño de Sagalassa valida Walker (Lepidoptera: Glyphipterigidae) en el sistema radical de 
la palma de aceite. Revista Palmas 21: 174-179. https://publicaciones.fedepalma.org/index.php/palmas/article/view/780/780

BAENA, M. L. 1993. Hormigas cazadoras del género Pachycondyla (Hymenoptera: Ponerinae) de la isla Gorgona y la planicie pacífica colombiana. Boletín del Museo Entomológico de la Universidad del Valle 1 (1): 13-21. https://bibliotecadigital. univalle.edu.co/bitstream/handle/10893/4536/2- \%20Hormigas $\% 20$ cazadoras \%20del \%20g \%c3\%a9nero \%20Pachycondyla. pdf? sequence $=1 \&$ isAllowed $=\mathrm{y}$

BERNAL, G.; BRAVO, V.; VEGA, C.; QUIROLA, P.; CHIRIBOGA, F.; INTRIAGO, R. 2015. Nuevas alternativas químicas para el control del barrenador de raíces (Sagalassa valida) de la palma aceitera. Asociación Nacional de Cultivadores de Palma Aceitera (ANCUPA), Boletín Técnico 12, Quito. Ecuador. 19 p.

BESTELMEYER, B. T. 2008. The trade-off between thermal tolerance and behavioural dominance in a subtropical South American ant community. Journal of Animal Ecology 69 (6): 9981009. https://doi.org/10.1111/j.1365-2656.2000.00455.x

CHUNG, A. Y. C.; HAMMOND, P. M.; EGGLETON, P.; SPEIGHT, M. R.; CHEY, V. K. 2000. A general survey of the Staphylinidae (Insecta: Coleoptera) assemblage in Sabah, Malaysia. Malayan Nature Journal 54 (4): 355-368.

CORAL, J.; CALVACHE, H.; SALAMANCA, J. C.; ALDANA, R. C.; CHÁVEZ, C. 2004. Reconocimiento de insectos depredadores del barrenador de raíces Sagalassa valida Walker en la palma de aceite. Revista Palmas 25: 232-239. https://publicaciones. fedepalma.org/index.php/palmas/article/view/1087/1087

CORREDOR RÍOS, A.; MARTÍNEZ LÓPEZ, G.; SILVA CARREÑO, A. 2008. Problemática de la pudrición del cogollo en Tumaco e instrumentos para su manejo y la renovación del cultivo. Revista Palmas 29 (3): 11-16. https://publicaciones. fedepalma.org/index.php/palmas/article/view/1353/1353

DAVIS, A. L. V.; PHILIPS, T. K. 2005. Effect of deforestation on a southwest Ghana dung beetle assemblage (Coleoptera: Scarabaeidae) at the periphery of Ankasa conservation area. Environmental Entomology 34 (5): 1081-1088. https://doi.org/10.1093/ ee/34.5.1081

DELSINNE, T.; LEPONCE, M; THEUNIS, L.; BRAET, Y.; ROISIN, Y. 2008. Rainfall influences ant sampling in dry forests. Biotropica 40 (5): 590-596. https://doi.org/10.1111/j.17447429.2008.00414.x

DUNN, O. J. 1961. Multiple comparisons among means. Journal of the American Statistical Association 56 (293): 52-64. https://doi. org/10.1080/01621459.1961.10482090

FEDEPALMA. 2015. The oil palm agroindustry in Colombia and the world 2010-2014. Statistical yearbook 2015. Federación Nacional de Cultivadores Palma de Aceite. Bogotá. Colombia. 181 p.

FERNÁNDEZ, F. 1991. Las hormigas cazadoras del género Ectatomma (Formicidae: Ponerinae) en Colombia. Caldasia 16 (79): 551-564. https://revistas.unal.edu.co/index.php/cal/article/ view/35681/36258

GALLEGO ROPERO, M. C.; ARMBRECHT, I. 2005. Depredación por hormigas sobre la broca del café Hypothenemus hampei (Curculionidae: Scolytinae) en cafetales cultivados bajo dos niveles de sombra en Colombia. Manejo Integrado de Plagas y Agroecología (Costa Rica) (76): 32-40. http://www.sidalc.net/ repdoc/A1859E/A1859E.PDF

GENTY, P. H. 1977. Las plagas y enfermedades de la palma de africana y del coco. Los lepidópteros minadores de raíces: Sagalassa valida Walker. Oleagineux 28 (2): 59-65.

GENTY, P. H.; DESMIER DE CHENON, R.; MORIN, J. P. 1978. Las plagas de la palma de aceitera en América Latina. Oleagineux 33 (7): 325-419.

GOEHRING, D. M.; DAILY, G. C.; SEKERÇIOGLU, C. H. 2002. Distribution of ground-dwelling arthropods in tropical countryside habitats. Journal of Insect Conservation 6: 83-91. https://doi.org/10.1023/A:1020905307244

GOITIA, W.; CERDÁ, H. 1998. Hormigas y otros insectos asociados a musáceas (Musa spp.) y su relación con Cosmopolites sordidus Germar (Coleoptera. Curculionidae). Agronomia Tropical (Venezuela) 48 (2): 209-224.

LACHAUD, J. P. 1990. Foraging activity y diet in some Neotropical ponerine ants. I. Ectatomma ruidum Roger (Hymenoptera: Formicidae). Folia Entomológica Mexicana 78: 241-256. https://ecosur.repositorioinstitucional.mx/jspui/ bitstream/1017/1041/1/0000187201_documento.pdf

LESTON, D. 1973. The ant mosaic-tropical tree crops and the limiting of pests and diseases. PANS Pest Articles \& News Summaries 19 (3): 311-341. https://doi.org/10.1080/09670877309412778

LESTON, D. 1978. A neotropical ant mosaic. Annals of the Entomological Society of America 71 (4): 649-653. https://doi. org/10.1093/aesa/71.4.649

LETOURNEAU, D. K.; JEDLICKA, J. A.; BOTHWELL, S. G.; MORENO, C. R. 2009. Effects of natural enemy biodiversity on the suppression of arthropod herbivores in terrestrial ecosystems. Annual Review of Ecology, Evolution and Systematics 40: 573592. https://doi.org/10.1146/annurev.ecolsys.110308.120320

LÓPEZ, R.; POTTER, D. A. 2000. Ant predation on eggs and larvae of the black cutworm (Lepidoptera: Noctuidae) and Japanese beetle (Coleoptera: Scarabaeidae) in Turfgrass. Environmental Entomology 29 (1): 116-125. https://doi.org/10.1603/0046225X-29.1.116

MAJER, J. D. 1972. The ant mosaic in Ghana cocoa farms. Bulletin Entomological Research 62 (2): 151-160. https://doi. org/10.1017/S0007485300047593

MAJER, J. D. 1976. The maintenance of the ant mosaic in Ghana cocoa farms. Journal of Applied Ecology 13 (1): 123-144. https:// doi.org/10.2307/2401933

McGLYNN, T. P.; DUNN, T.; WAYMAN, E.; ROMERO, A. 2010. A thermophile in the shade: light-directed nest relocation in the Costa Rican ant Ectatomma ruidum. Journal of Tropical Ecology 26 (5): 559-562. https://doi.org/10.1017/S0266467410000313

MERA VELASCO, Y. A.; GALLEGO ROPERO, M. C.; ARMBRECHT, I. 2010. Interacciones entre hormigas e insectos en follaje de cafetales de sol y sombra, Cauca-Colombia. Revista Colombiana de Entomología 36 (1): 116-126. http://www.scielo.org.co/ $\mathrm{pdf} / \mathrm{rcen} / \mathrm{v} 36 \mathrm{n} 1 / \mathrm{v} 36 \mathrm{n} 1 \mathrm{a} 20 . \mathrm{pdf}$

NUNES, F. A.; MARTINS SEGUNDO, G. B.; VASCONCELOS, Y. B.; AZEVEDO, R.; QUINET, Y. 2011. Ground-foraging ants (Hymenoptera: Formicidae) and rainfall effect on pitfall trapping in a deciduous thorn woodland (Caatinga), Northeastern Brazil. Revista de Biología Tropical 59 (4): 1637-1650. https://doi. org/10.15517/rbt.v59i4.3426

PEARSON, K. 1895. VII. Notes on regression and inheritance in the case of two parents. Proceedings of The Royal Society of London 58: 240-242. https://doi.org/10.1098/rspl.1895.0041

PEÑA ROJAS, E. A.; JIMÉNEZ OCHOA. O. D. 1994. Distribución del daño del insecto Sagalassa valida Walker en el sistema radical de la palma de aceite (Elaeis guineensis Jacq.) en la zona de Tumaco. Revista Palmas 15 (3): 19-23. https://publicaciones. fedepalma.org/index.php/palmas/article/view/442/442

PFEIFFER, M.; TUCK, H. C.; LAY, T. C. 2008. Exploring arboreal ant community composition and co-occurrence patterns in plantations of oil palm Elaeis guineensis in Borneo and Peninsular Malaysia. Ecography 31 (1): 21-32. https://doi.org/10.1111/ j.2007.0906-7590.05172.x

PINZÓN ANDERSSON, L. I. 1995. Aspectos generales sobre la biología y manejo del insecto Sagalassa valida Walker. barrenador de las raíces en la palma de aceite en Palmas de Tumaco. Revista Palmas 16 (2): 17-23. https://publicaciones.fedepalma. org/index.php/palmas/article/view/468/468

PRECIADO, C. A.; BASTIDAS P., S.; BETANCOURTH, C.; PEÑA, E.; REYES, R. 2011. Predicción y control de la cosecha en el híbrido interespecífico Elaeis oleifera x Elaeis guineensis en la zona palmera occidental de Colombia I. I. Determinación del período de madurez para obtener racimos con alto contenido de aceite. Corpoica Comunicado Técnico Agropecuário 12 (1): 5-12. https://doi.org/10.21930/rcta.vol12_num1_art:210 
REYES, C. R. 2012. Respuesta fisiológica de la palma aceitera (Elaeis guineensis Jacq.) a la disponibilidad de agua en el suelo. Ph. D. Thesis. Universidad de Costa Rica. San José de Costa Rica. 210 p.

RIERA-VALERA, M. A.; PÉREZ-SÁNCHEZ, A. J. 2009. Notas acerca de la dieta de Ectatomma ruidum (Roger 1861) (Hymenoptera: Formicidae: Ectatomminae) en un jardín venezolano. Boletin de la Sociedad Entomológica Aragonesa (44): 550-552. http://sea-entomologia.org/Publicaciones/PDF/ BOLN44/550_552BSEA44NBEctatommadieta.pdf

SÁENZ A., A.; OLIVARES, W. 2008. Velocidad de desplazamiento del primer instar de Sagalassa valida (Lepidoptera: Glyphipterigidae). Revista Colombiana de Entomología 34 (1): 57-61. http://www.scielo.org.co/pdf/rcen/v34n1/v34n1a07.pdf

SANTAMARÍA, C.; ARMBRECHT, I.; LACHAUD, J. 2009. Nest distribution and food preferences of Ectatomma ruidum (Hymenoptera: Formicidae) in shaded and open cattle pastures of Colombia. Sociobiology 53 (2B): 517-541. https://hal.archives-ouvertes.fr/hal-02131957/document

SARMIENTO, A.; BENÍTEZ, E.; ALDANA, R. 2005. Descripción de la capacidad depredadora de las hormigas Pachycondyla harpax y Pachycondyla obscuricornis sobre Sagalassa valida Walker, barrenador de raíces en palma de aceite. Revista Palmas 26 (2): 23-38. https://publicaciones.fedepalma.org/index.php/ palmas/article/view/1130/1130

SCHATZ, B.; LACHAUD, J. P. 2008. Effect of high nest density on spatial relationships in two dominant ectatommine ants (Hymenoptera: Formicidae). Sociobiology 51 (3): 623-643. https:// www.academia.edu/29035648/Effect_of_high_nest_density on_spatial_relationships_in_two_dominant_ectatommine_ants_ Hymenoptera_Formicidae_Sociobiology

SCHATZ, B.; LACHAUD, J. P.; BEUGNON, G. 1996. Polyethism within hunters of the ponerine ant, Ectatomma ruidum Roger (Formicidae, Ponerinae). Insectes Sociaux 43: 111-118. https:// doi.org/10.1007/BF01242563

SIEMANN, E.; TILMAN, D.; HAARSTAD, J.; RITCHIE, M. 1998. Experimental tests of the dependence of arthropod diversity on plant diversity. American Naturalist 152 (5): 738-751. https:// doi.org/10.2307/2463851

VELÁZQUEZ, J.; JOLY, L. J.; GARCÍA, J. L.; ROMERO, Y.; GONZÁLEZ M.; MEDINA, M. 2006. Enemigos naturales del "Picudo del Agave" Scyphophorus acupunctatus Gyllenhal (Coleoptera: Curculionidae) en el Estado Falcón, Venezuela. Entomotropica 21 (3): 185-193. http://saber.ucv.ve/ojs/index.php/ rev_ento/article/view/7494/7407

WANG, W. Y.; FOSTER, W. A. 2015. Ground-foraging ant communities vary with oil palm age. Basic and Applied Ecology 17 (1): 21-32. https://doi.org/10.1016/j.baae.2015.08.009

WAY, M. J.; KHOO, K. C. 1992. Role of ants in pest management. Annual Review of Entomology 37: 479-503. https://doi. org/10.1146/annurev.en.37.010192.002403

WEISSER, W. W.; SIEMANN, E. (Eds.). 2004. Insects and ecosystem function. Ecological studies, vol 173. Springer-Verlag. Berlin. Germany: $440 \mathrm{p}$.

ZENNER DE POLANIA, I. 1994. Hormigas depredadoras en el ecosistema de palma de aceite. Revista Palmas 15 (4): 33-39. https://publicaciones.fedepalma.org/index.php/palmas/article/ view/453/453

\section{Origin and funding}

The studies reported here were conducted as part of the routine research activities of the Colombian Corporation of Agricultural Research, with funding from the Ministry of Agriculture (Ministerio de Agricultura, Pecuaria y Abastecimiento de Colombia).

\section{Author contribution}

The study was conceived by the first author, who also participated in the establishment of the transects, identification of the specimens and was instrumental in data analysis and writing of the manuscriptThe co-author conducted the field studies and the identification of specimens, compiled the data, participated in the data analysis and in writing the manuscript. 